\title{
Clinical and epidemiological profile of patients diagnosed with multiple sclerosis in João Pessoa, Paraíba, Brazil
}

\author{
Perfil clínico-epidemiológico de pacientes com diagnóstico de esclerose múltipla na \\ cidade de João Pessoa, Paraíba, Brasil \\ André Augusto Lemos Vidal de Negreiros, Rilva Lopes de Sousa-Munõz, Bianca Etelvina Santos de Oliveira, \\ Paulo Virgolino da Nóbrega, Laíse Leilane Dias Monteiro
}

\begin{abstract}
Prevalence rates of multiple sclerosis (MS) suggest an interrelationship between genetic and environmental factors, ranging worldwide. Objectives: Clinical and epidemiological characterization of MS patients in João Pessoa, Paraíba city. Methods: Study involving patients treated in five services in the city. Results: It included 87 patients with MS, representing a prevalence of 12.0 cases/100,000 population, mainly women (77\%) and white people (66.7\%) with mean age of 43 years and average age of the first outbreak of 32.2 years. Motor symptoms (65.5\%) and relapsing-remitting clinical form (78.2\%) predominated; the average of the Expanded Disability Status Scale (EDSS) scores was 3.5 and $72 \%$ used a type of immunomodulatory drug. There was a positive correlation between the number of outbreaks and the duration of the disease with EDSS scores. Conclusions: The prevalence of the disease is considered average. The clinical and epidemiological characteristics are in line with most similar Brazilian studies.
\end{abstract}

Keywords: multiple sclerosis, epidemiology, prevalence.

\section{RESUMO}

As taxas de prevalência da esclerose múltipla (EM) sugerem uma inter-relação entre fatores genéticos e ambientais, variando mundialmente. Objetivos: Caracterização clínico-epidemiológica dos pacientes com EM na cidade de João Pessoa, Paraíba. Métodos: 0 estudo envolveu pacientes atendidos em cinco serviços da cidade. Resultados: Incluíram-se 87 pacientes com EM, que representou a prevalência de 12,0 casos/100.000 habitantes, com predomínio no sexo feminino (77\%) e em brancos (66,7\%), idade média de 43 anos e idade média do primeiro surto de 32,2 anos. Predominaram os sintomas motores (65,5\%) e a forma clínica remitente-recorrente (78,2\%); a média dos escores da Escala de Status de Incapacidade Expandida (EDSS) foi de 3,5 e 72\% utilizava imunomoduladores. Houve correlação positiva entre o número de surtos e dos anos de doença com o escore EDSS. Conclusões: A prevalência da doença no município é considerada média. As características clínico-epidemiológicas estão em consonância com a maioria dos estudos brasileiros semelhantes.

Palavras-chave: esclerose múltipla, epidemiologia, prevalência.

Multiple sclerosis (MS) is an inflammatory, demyelinating and degenerative disease of the central nervous system and whose etiology is still unknown ${ }^{1,2,3,4}$, but supposedly associated with the interaction of genetic, infectious and environmental factors ${ }^{1}$. This disease is characterized by repeated episodes of neurological and wide variety of signs and symptoms $s^{3,5,6}$, affecting more young adults, caucasians and females ${ }^{2}$. The prevalence of MS varies considerably worldwide. It is estimated that South America has low prevalence (less than 5 cases per 100,000 population), while in the Northern Hemisphere, the prevalence is greater than 30 cases per
100,000 inhabitants ${ }^{3,6}$. Although Brazil is considered an area of low prevalence, there are regions of medium prevalence (between 5 and 30 cases per 100,000 population), as shown by studies in cities in the Southeast region of Brazil ${ }^{3,4,7,8,9,10}$. The few studies conducted in the Northeast also corroborate this low prevalence estimate ${ }^{1,6}$. Systematic review study on the prevalence of in the South America indicate that MS prevalence rate ranging from 1.48 to 17 per 100.000 inhabitants $^{11,12}$.

João Pessoa is the capital of the state of Paraíba, located on the coast of northeastern Brazil, the eastern end of the state, with southern latitude $7^{\circ} 06^{\prime} 54^{\prime \prime}$ and west longitude $34^{\circ} 51^{\prime} 46^{\prime \prime}$.

Universidade Federal da Paraíba, Joao Pessoa PB, Brazil.

Correspondence: André Augusto Lemos Vidal de Negreiros; Rua Presidente Arthur Bernardes, 433/casa 102; 58035-300 João Pessoa PB, Brasil;

E-mail: andrelvn1@hotmail.com

Conflict of interest: There is no conflict of interest to declare.

Received 25 August 2014; Received in final form 24 April 2015; Accepted 15 May 2015. 
Its population consists of 723,515 inhabitants $^{13}$, in an area of $211475 \mathrm{~km}^{2}$. Much of the city is situated on low-lying coastal plains, with an approximate elevation of 20 meters above the sea. According to the Brazilian Institute of Geography and Statistics (IBGE), its location is the Mesoregion of the Paraíba Forest, João Pessoa microrregion ${ }^{14}$.

The prevalence rates of MS in the world suggest the role of the interrelation between genetic and environmental factors ${ }^{5}$. Given the broad geographical spread and ethnic diversity of Brazil, it is believed that the frequency of MS varies between different regions ${ }^{5}$. In the state of Paraíba, there are no published studies to date on the epidemiological and clinical profile of multiple sclerosis. However, there are various ethnic groups that formed Paraíba's population. Before the arrival of the Portuguese, Paraiba was occupied by Potiguara and Tabajara Indians, and from the early sixteenth century, Europeans, predominantly Portuguese, colonized Paraíba. At the time of the Dutch invasion, between 1634 and 1654, there are reports of many inter-racial marriages. The black population had less presence in the formation of Paraíba population when compared to other states in the Northeast ${ }^{15,16}$. According to the last census conducted by IBGE in 2010, from an ethnic-racial point-of-view, Paraíba has a population with a prevalence of mixed races $(52.3 \%)$, followed by whites $(42.6 \%)$, blacks $(3.9 \%)$ and, finally, indigenous and yellows $(0.36 \%)$, and those with no racial statement $(0.79 \%)^{13}$.

The aim of this study is to describe the clinical and epidemiological characteristics of patients diagnosed with MS living in the city of João Pessoa, Paraíba, Brazil.

\section{METHOD}

The model of this study was observational and retrospective descriptive, involving patients followed in the following care services to patients with multiple sclerosis in the city of João Pessoa, Paraíba: Reference Center for Multiple Sclerosis Paraíba (CREMPB), Paraiba Association of Patients with Multiple Sclerosis (APBEM), Neurology clinics of the Lauro Wanderley University Hospital and two private clinics in neurology. According to a study conducted by the Federal Board of Medicine, there are seven clinical neurologists in João Pessoa ${ }^{17}$.

The study was conducted between November 2012 and November 2013. Patients were classified according to the revised McDonald criteria in $2010^{18}$. Only those patients dwelling in João Pessoa at the moment of theur diagnosis of MS were included in this study. Therefore, the geographical unit considered in this survey was the city of João Pessoa and its metropolitan area.

Data were collected according to the method proposed by the Latin American Committee for Treatment and Research in Multiple Sclerosis (LACTRIMS) ${ }^{19}$, from a review of medical records of patients. Participants were informed about the objectives and procedures of the study, and included in it after signing the consent form. Data were also collected from the $\mathrm{IBGE}^{14}$. This study was approved by the Ethics Committee in Research of the Lauro Wanderley University Hospital, under CAE 10897812.1.0000.5183, with the approval opinion no. 211367.

The variables analyzed were gender, age, ethnicity, clinical presentation, patient age at diagnosis, patient age at first onset, time since diagnosis, duration of clinical manifestation of the disease, number of relapses, predominant symptoms, use of disease-modifying drugs and symptomatic drugs. The clinical presentation was defined based on the study of Lublin, in the categories relapsing-remitting (RR), secondary progressive (SP) and primary progressive (PP).

The assessment of functional capacity of patients was performed by the Expanded Scale of Incapacity State (Expanded Disability Status Scale or EDSS), the scale most often used to evaluate patients with multiple sclerosis. This scale has 20 items, with scores ranging from 0 to 10 , and whose score increases along with the degree of patient impairment, with greater focus on the ability to ambulate ${ }^{19,20,21}$.

We calculated mean and standard deviation for continuous variables, absolute and relative frequencies of categorical variables, calculus of the prevalence rate in the period, and its gender ratio. The prevalence day for analysis was July 27,2013. An analysis of simple linear Spearman correlation for quantitative variables was performed. Analyses were performed using the SPSS software, version 20.0 for Windows.

\section{RESULTS}

In the services for the care of patients with MS, there was a record of 164 patients diagnosed with the disease. Ouf of this number, 77 were excluded from the study due to their not living in the considered geographic unit, the City of João Pessoa, at the moment of diagnosis.

João Pessoa has an area of $211475 \mathrm{~km}^{2}$ and 723,515 inhabitants estimated on the prevalence day. A total of 87 patients were identified among the inhabitants of the city of João Pessoa, representing a prevalence of 12.0 cases/100,000 inhabitants. Out of 87 patients who were included in the study, 67 were women, verifying a ratio between females and males 3.3. Regarding ethnicity, 58 were white, 26 pheodermic and black 3 . It was found that the most common clinical form of the disease in the sample relapsing-remitting (RR), 68 cases $(78.2 \%)$, followed by the way secondary progressive (SP) (21.8\%), and no patient had primary progressive (PP) manner.

The age, at which the diagnosis, was done age of first onset, and the time of diagnosis and duration of disease (clinical signs) was performed are shown in Table 1.

Motor symptoms were most often presented by patients (65.5\%), followed by cerebellar symptoms (35.6\%), sensitive (33.3\%), visual $(32.2 \%)$ and those related to the brainstem (10.3\%). We observed a positive correlation statistically significant of moderate magnitude between the number of outbreaks and the global score of the Expanded Disability Status 
Scale $($ EDSS) $(r h o=0.38, p<0.0005)$. There was a significant positive correlation, but small in magnitude, between this score and duration of disease ( $\mathrm{rho}=0.271, \mathrm{p}=0.011$ ).

Table 2 shows the clinical and demographic characteristics of patients according to ethnicity. There were no statistically significant differences between the clinical categories evaluated. However, there was greater distribution of women among white patients, while the opposite occurred among pheodermic.

The disease modifying drug most used by the patients was beta interferon at various doses (Figure). Most patients did not use any symptomatic medication (78.2\%) to alleviate the symptoms of the disease like depression, paresthesia, spasticity and urinary incontinence. Those using symptomatic drugs used amantadine hydrochloride (5.7\%), fluoxetine (4.0\%), baclofen $(3.4 \%)$ and gabapentin (1.7\%). Other medications, at lower frequencies, were used by $6.9 \%$ of patients.

\section{DISCUSSION}

In the city of João Pessoa, the prevalence of MS was found to be 12 cases per 100,000 inhabitants, conforming an area of average prevalence of the disease, according to studies

Table 1. Clinical and demographic characteristics of patients diagnosed with multiple sclerosis in the city of João Pessoa, Paraíba, Brazil, between November 2012 and November 2013 ( $n=87$ ).

\begin{tabular}{lcc}
\hline Variables & Averages & Standard deviation \\
\hline Age (years) & 43.0 & 13.3 \\
Age at the diagnosis (years) & 36.1 & 11.6 \\
Age at 1st onset (years) & 32.2 & 11.6 \\
Time of diagnosis (years) & 3.9 & 5.9 \\
Disease Duration (years) & 10.6 & 8.0 \\
Number of outbreaks & 3.3 & 1.2 \\
EDSS Score & 3.5 & 1.95 \\
\hline
\end{tabular}

EDSS: Expanded Disability Status Scale. by Kurtzke $e^{21,22,23}$, and in line with studies conducted in cities in Southeastern Brazil $23,4,5,10,24,25$, however, it is not compatible with the findings of the study conducted in Recife, Pernambuco, Brazil, 130 km north of João Pessoa, in 2004 by presenting the latter a rate significantly below the other reported in the literature (Table 3).

This low prevalence found in the study by Ferreira et al. may be related to the fact that this research was conducted at a single referral center in the geographical unit considered ${ }^{6}$. Moreover, one can also consider that there are difficulties in accessing health services and referral to specialist neurologists, beyond the problem of obtaining additional tests to support the diagnosis of MS, factors that may underestimate the actual number of cases. In addition, the comparisons between the capital, one should take into account the differences in the periods of data collection.

White ethnicity was predominant, corroborating most epidemiological studies in Brazil $2,3,4,5,10,24,25,26$, except for the study of Ferreira et al. ${ }^{6}$, in which $93.2 \%$ were mixed race (African descent). In this respect, classifying patients according to their ethnicity in a country with great miscegenation as Brazil is not an easy task. We had difficulty in classifying patients as pheodermic, black or mulatto ${ }^{1,3}$. The calculation of the sex ratio also indicated a greater predisposition of females to MS. A similar finding is reported in other studies on clinical and epidemiological profile of patients with the disease.

The age average and the first outbreak average of patients, the average disease duration in years, the average number of outbreaks, the average of the EDSS global score, as well as the predominance of RR are consistent with the literature $^{2-5,10,24,26}$. The diagnosis time in years was greater than the Swedish study Skoog et al. ${ }^{27}$, in which the time was two years, while in this study it was 3.9 years. However, this date can be explained by the fact that Sweden is a country with wide access to health and wide availability of complementary tests, compared to those observed in Brazil. Nowadays

Table 2. Clinical and epidemiological characteristics of patients diagnosed with multiple sclerosis in the city of João Pessoa, Paraíba, Brazil, between November 2012 and November 2013 ( $n=87$ ).

\begin{tabular}{|c|c|c|c|c|}
\hline Characteristcs & White & Ethnicity Pheodermic & Black & $p$ \\
\hline Gender (\%) & & & & 0.015 \\
\hline Male & 40.0 & 55.0 & 5.0 & \\
\hline Female & 74.6 & 22.4 & 3.0 & \\
\hline Clinical presentation (\%) & & & & NS \\
\hline $\mathrm{RR}$ & 66.2 & 30.9 & 2.9 & \\
\hline SP & 68.4 & 26.3 & 5.3 & \\
\hline $\mathrm{PP}$ & - & - & - & \\
\hline EDSS (average, SD) & $3.7 \pm 2.2$ & $3.4 \pm 1.5$ & $2.2 \pm 1.3$ & NS \\
\hline Age (average, SD) & $44.0 \pm 14$ & $39.0 \pm 12$ & $48 \pm 18$ & NS \\
\hline Disease duration (years - average, SD) & $12 \pm 9$ & $8 \pm 5$ & $13 \pm 11$ & NS \\
\hline Number of outbreaks (average, SD) & $3 \pm 1$ & $3 \pm 1$ & $3 \pm 1$ & NS \\
\hline Age at 1 st onset (average, SD) & $32 \pm 12$ & $32 \pm 10$ & $35 \pm 16$ & NS \\
\hline Time of diagnosis (years - average, SD) & $5 \pm 7$ & $2 \pm 3$ & $8 \pm 10$ & NS \\
\hline
\end{tabular}

RR: Relapsing-remitting; SP: Secondary progressive; PP: Primary-Progressive; EDSS: Expanded Disability Status Scale; SD: standard deviation; NS: Not statistically significant $(p<0.05)$. 


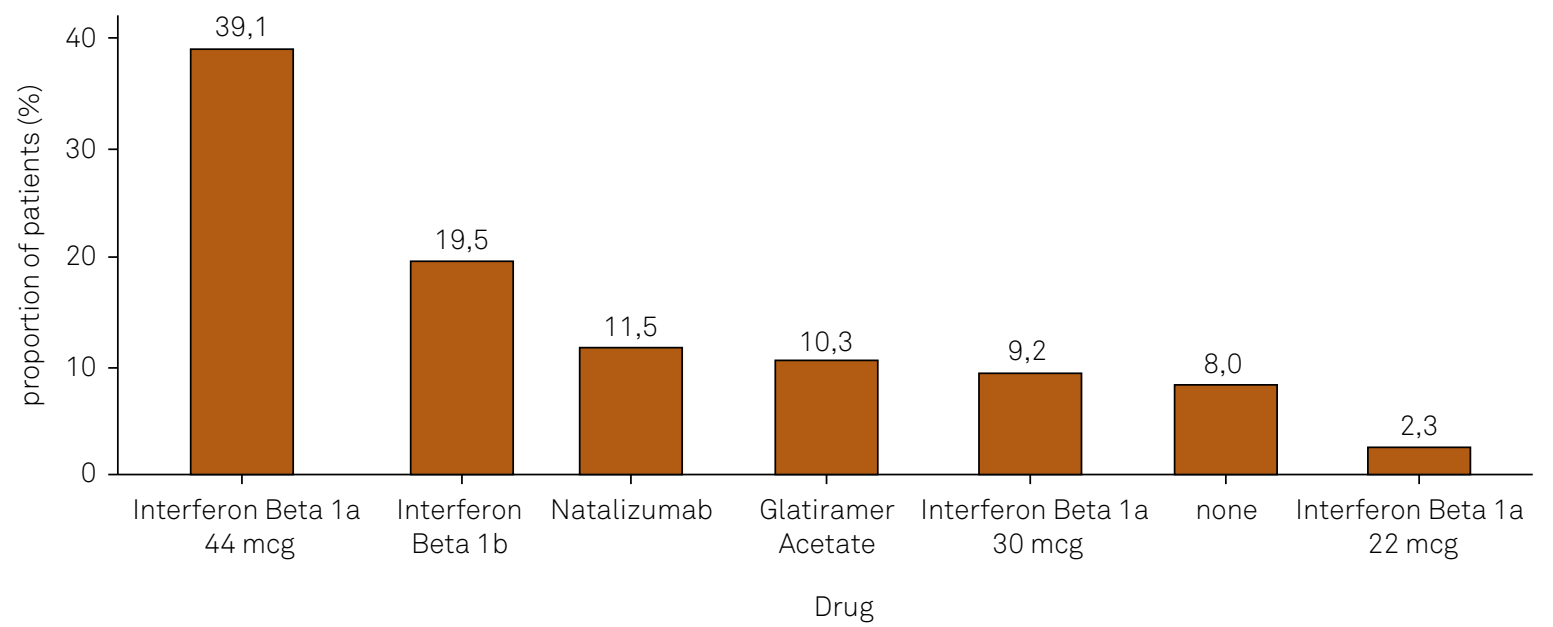

Figure. Frequency of use of disease modifying drugs in patients with multiple sclerosis in the city of João Pessoa, Paraíba, Brazil, between November 2012 and November 2013 ( $n=87$ ).

Table 3. Comparison between the results of epidemiological studies on multiple sclerosis performed in Brazil.

\begin{tabular}{lcccc} 
Studies (authors, year) & Geographic unit & Number of patients & Gender ratio F:M & Prevalence \\
\hline Moreira et al. (2000) & SP & 302 & $3.5: 1$ & $1.8: 1$ \\
Arruda et al. (2001) & PR & 200 & $4.1: 1$ & - \\
Ferreira et al. (2004) & PE & 118 & $3.3: 1$ & $4.0: 1$ \\
Fragoso e Peres (2005) & SP & 81 & $3.1: 1$ & - \\
Cardoso et al. (2006) & BA & 121 & $3.7: 1$ & - \\
Grzesiuk (2006) & MT & 20 & $2.9: 1$ & - \\
Santos et al. (2006) & SP & 283 & $2.5: 1$ & - \\
Finkelsztejn et al. (2009) & RS & 67 & $3.3: 1$ & 12.5 \\
Ribeiro et al. (2011) & MG & 35 & $3.3: 1$ \\
Lana-Peixoto et.al (2012) & MG & 409 & 18.1 \\
Present Study (2013) & PB & & 12.0 \\
\hline
\end{tabular}

the diagnosis is more easily performed due to more access diagnostic tools. In addition there is increased life expectancy, that contributes for increased of prevalence rate.

The prevalence of motor, cerebellar, sensory and visual symptoms was also observed in other samples ${ }^{2,4}$. The correlations observed between functional capacity assessed by the EDSS score, despite not reaching statistical significance in studies of Arruda et al. ${ }^{24}$. and Ferreira et al. ${ }^{6}$. The correlation observed in this study corroborates most international studies, which shows that the natural course of multiple sclerosis over the years, if not promptly treated with disease-modifying drugs, is associated to the accumulation of neurological deficits $^{20}$. Patients with the RR form may develop neurological disabilities gradually, often due to the inability to complete recovery of an outbreak ${ }^{20}$. In the study cohort, Skoog et al., 202 patients having the relapsing-remitting clinical form progressed to secondary progressive form, at an interval of 12 years, progressing with increased EDSS score ${ }^{27}$. However, in this same study, it is suggested that the best parameter to predict the disabilities that the disease can cause is the disease progression index, not the EDSS, considering the latter, after several outbreaks of the disease, can suffer influence of random factors ${ }^{23,27,28}$.
Regarding the distribution of disease modifying drugs among patients, there were similar results when compared to those found in the study by Cardoso et al. ${ }^{1}$ We did not find, even in the most recent studies of clinical and epidemiological profile of MS, the use of Natalizumab, a humanized monoclonal antibody, a drug already in use by the participants of this study, since it is a drug with recent availability in the market.

It is important to emphasize the limitations of this study, especially the fact that it is a retrospective study and convenience sampling may reduce its external validity. Since these estimates are based on data from a capital, they do not reflect the situation of the state or the region as a whole. However, the aim of this study was to describe the clinical and epidemiological characteristics of patients with MS in the city of João Pessoa, where there is a major referral center for the treatment of MS for patients from all over the state, which allowed to cover the observation of the vast majority of patients with the disease in the city. We expect to contribute to the descriptive epidemiological study of MS, and encourage researchers to develop more studies on this disease in different regions of Brazil, especially in the Northeast, a region with limited research on this topic and its wide ethnic diversity. 
1. Cardoso E, Fukuda T, Pereira J, Seixas J, Miranda R, Rodrigues $B$ et al. Clinical and epidemiological profile of multiple sclerosis in a reference center in the State of Bahia, Brazil. Arq Neuropsiquiatr. 2006;64(3B):727-30. doi:10.1590/S0004-282X2006000500005

2. Grzesiuk, A. K. [Clinical and epidemiologic characteristics of 20 patients with multiple sclerosis in Cuiabá - Mato Grosso, Brazil]. Arq Neuropsiquiatr. 2006;64(3A):635-8. Portuguese. doi:10.1590/S0004-282X2006000400022

3. Ribeiro SBF, Maia DF, Ribeiro JB, Cardoso FAG, Silva C. Clinical and epidemiological profile of patients with multiple sclerosis in Uberaba, Minas Gerais, Brazil. Arq Neuropsiquiatr. 2011;69(2A):184-7. doi:10.1590/S0004-282X2011000200008

4. Lana-Peixoto MA., Frota ERC., Campos GB., Monteiro LP.The prevalence of multiple sclerosis in Belo Horizonte, Brazil. Arq Neuropsiquiatr. 2012;70(2):102-7. doi:10.1590/S0004-282X2012000200006

5. Moreira, MA, Felipe E, Mendes, MF, Tilbery, CP. [Multiple sclerosis: descriptive study of the clinical forms in 302 cases]. Arq Neuropsiquiatr. 2000;58(2B):460-6. Portuguese. doi:10.1590/S0004-282X2000000300010

6. Ferreira MLB, Machado MI, Vilela ML, Guedes MJ, Ataíde Juniorr L, Santos $S$ et al. [Epidemiology of 118 cases of multiple sclerosis after 15 years of follow-up on the reference Center of Hospital of Restauração, Recife, Pernambuco, Brazil]. Arq Neuropsiquiatr. 2004;62(4):1027-32. Portuguese. doi:10.1590/S0004-282X2004000600018

7. Callegaro D, Goldbaum M, Morais L, Tilbery CP, Moreira MA, Gabbai AA et al. The prevalence of multiple sclerosis in the city of São Paulo, Brazil, 1997. Acta Neurol Scand. 2001;104(4):208-13. doi:10.1034/j.1600-0404.2001.00372.x

8. Polman CH, Reingold SC, Banwell B, Clanet M, Cohen JA, Filippi M, et al. Diagnostic criteria for multiple sclerosis: 2010 revisions to the McDonald criteria. Ann Neurol. 2010;69(2):292-302. doi:10.1002/ana.22366

9. Rocha F, Herrera LC, Morales RR. Multiple sclerosis in Botucatu, Brazil: a population study. Mult Scler. 2002;8 Suppl:S41.

10. Gama PD, Trigo LX, Andrade CRR, Sala CR. Epidemiological study of multiple sclerosis in the city of Sorocaba, Brazil. Arq Neuropsiquiatr. 2004;62 Suppl1:S13.

11. Cristiano E, Patrucco L, Rojas JI. A systematic review of the epidemiology of multiple sclerosis in South America. Eur J Neurol 2008;15(12):1273-8. doi:10.1111/j.1468-1331.2008.02330.x

12. Cristiano E, Rojas J, Romano M, Frider N, Machnicki G, Giunta $D$ et al. The epidemiology of multiple sclerosis in Latin America and the Caribbean: a systematic review. Mult Scler. 2013;19(7):844-54. doi:10.1177/1352458512462918

13. Fragoso YD, Peres M. Prevalence of multiple sclerosis in the city of Santos SP. Rev Bras Epidemiol. 2007;10(4):479-82. doi:10.1590/S1415-790X2007000400005
14. Instituto Brasileiro de Geografia e Estatística. Contagem populacional. Rio de Janeiro: Instituto Brasileiro de Geografia e Estatística; 2010 [cited 2013 Aug 15). Avaiable from: http://cidades. ibge.gov.br/painel/painel.php?codmun $=250750$

15. Ochotorena MJ. Uma breve análise da dinâmica demográfica da Cidade de João Pessoa [monografia]. João Pessoa: Universidade Federal da Paraíba; 2006.

16. Guedes PHMQ. A colonização do sertão da Paraíba: agentes produtores do espaço e contatos interétnicos (1650-1730). Okara Geogr Debate. 2007;1:128-30.

17. Oliveira CMS, Menezes MV, Gonçalves RC. Ensaios sobre a América portuguesa. João Pessoa: Editora Universitária/UFPB; 2009.

18. Scheffer M, Biancarelli A, Cassenote A, coordinators. Demografia médica no Brasil: dados gerais e descrições de desigualdades: relatório de pesquisa. São Paulo: Conselho Federal de Medicina; 2011.

19. Latin American Committee for Treatment and Research in Multiple Sclerosis-LACTRIMS. Metodologia para a realização de estudo epidemiológico. Available from: http://www.bctrims.org.br/

20. Lublin FD. Clinical features and diagnosis of multiple sclerosis. Neurol Clin. 2005;23(1):1-15. doi:10.1016/j.ncl.2004.09.003

21. Kurtzke JF. Rating neurologic impairment in multiple sclerosis: an expanded disability status scale (EDSS). Neurology. 1983;33(11):1444-52. doi:10.1212/WNL.33.11.1444

22. Felipe E, Mendes MF, Moreira MA, Tilbery CP. [Comparative analysis of two clinical scales for multiple sclerosis: review of 302 cases]. Arq Neuropsiquiatr. 2000;58(2A):300-3. Portuguese. doi:10.1590/S0004-282X2000000200016

23. Kurtzke JF, Page WF. Epidemiology of multiple sclerosis in US veterans: VII. Risk factors for MS. Neurology. 1997;48(1):204-13. doi:10.1212/WNL.48.1.204

24. Arruda WO, Scola RH, Teive HAG, Werneck LC. Multiple sclerosis: re-port on 200 cases from Curitiba, Southern Brazil and comparison with other Brazilian series. Arq Neuropsiquiatr. 2001;59(2A):165-70. doi:10.1590/S0004-282X2001000200002

25. Santos EC, Yokota M, Dias NFR. [Multiple sclerosis: study of patients with relapsing-remitting form registered at Minas Gerais Secretary State for Health]. Arq Neuropsiquiatr. 2007;65(3B):885-88. Portuguese. doi:10.1590/S0004-282X2007000500032

26. Finkelsztejn A, Cristovam RA, Moraes GS, Lopes MG, Silva AV, Garcia MS et al. Clinical features of multiple sclerosis in the south of Brazil: a partial analysis. Arq Neuropsiquiatr. 2009;67(4):1071-5. doi:10.1590/S0004-282X2009000600021

27. Skoog B, Runmarker B, Winblad S, Ekholm S, Anderson O. A representative cohort of patients with non-progressive multiple sclerosis at the age of normal life expectancy. Brain. 2012;135(3):900-11. doi:10.1093/brain/awr336

28. Leray E, Yaouanq J, Le Page E, Coustans M, Laplaud D, Oger J et al. Evidence for a two-stage disability progression in multiple sclerosis. Brain. 2010;133(7):1900-13. doi:10.1093/brain/awq076 